DOI: $10.19195 / 2353-8546.6 .18$

\author{
SIMONA MITROIU, ELENA ADAM \\ Alexandru loan Cuza University (lasi, Romania)*
}

\title{
Women's Narratives of Displacement and their Afterlife
}

Women's Narratives of Displacement and their Afterlife. This paper focuses on the connection between life writing and postmemory. The case of Anița Nandriș-Cudla's life writing is presented based on its unique status: women's testimonies are rare in Romanian memory discourse, and when present, they are limited to known intellectual figures. Moreover, the displacement narratives occupy a small place in Romania's post-1989 collective memory discourse and, as survivors of deportation inexorably pass away, life writing becomes increasingly important in the transmission of memory. This paper argues that increasing attention to the narratives of the past traumas can develop the intergenerational transmission of memory and knowledge. The process of coming to terms with the past must offer space to alternative memories and narratives with which, the research shows, second or third generations can relate, based on similarities and resemblance, and in this way develop an empathic understanding of current events.

Keywords: displacement, women, life writing, postmemory, intergenerational transmission of memory and knowledge

Женские свидетельства о переселениях лиц и их жизнь после смерти. В данной статье основное внимание уделяется связи между биографическими писаниями и записями о прошедших событиях (postmemory). Писания о жизни Аниты Нандрис Кудла представлены здесь благодаря их уникальному статусу, так как женские свидетельские показания очень редки в румынских произведениях и записях, связанных с историческими событиями и, даже если они присутсвуют, они ограничиваются показаниями известных интеллектуальных личностей. Кроме того, записи о переселениях занимают небольшое место в писаниях коллективной памяти Румынии после 1989-го года и, вместе со смертью тех, кто остался в живых после депортаций, писание о их жизни становится все более важным в процессе передачи памяти. В данной работе утвержда-

* Address: Department of Interdisciplinary Research in Social-Human Sciences, Alexandru Ioan Cuza University, Iasi, Romania. E-mail: adamelena9@yahoo.com. 
ется, что повышенное внимание к прошлым травмам способствует передаче воспоминаний и знаний следующим поколениям. Восприятие прошлого должно также оставить место для альтернативных воспоминаний и записей, в которых, как показывают исследования, вторые и третьи поколения могут найти много общего и таким образом развивать в себе способность эмпатически понимать текущие события.

Ключевые слова: переселения, женщины, биографические писания, записи о прошедших событиях

Many victims of totalitarian regimes, including a large number of those under the Romanian communist regime, never had the option of writing their memoirs. Many of those who survived prison, deportation, or torture were kept alive by the hope of not only preserving their own lives, but also by the desire to act as witnesses to later generations. The majority of written testimonies are provided by intellectuals, or by people with educated backgrounds and living in urban areas. Anne Applebaum points out that despite the fact that the majority of Gulag prisoners were peasants and uneducated workers, research seldom includes this category of experience, as the majority of these people were not able to write their memories.

Even less represented are the testimonies of women: mothers, wives, and widowed heads of households whose valiant efforts to keep their families together and provide for them amidst great calamity are severely underrepresented in the collective memory and written accounts of the regime. Anița Nandriş-Cudla is an exception, in that her published testimony has won the attention of a wide audience. She was a Romanian farmer deported to Siberia by the Soviets during the Second World War. Her testimony, Twenty Years in Siberia - 20 de ani in Siberia (1991), published after the fall of the Romanian communist regime and translated in English in 1998, is one of the few life narratives that make possible the transgenerational transmission of memory regarding this era. Her testimony is just one example of the trauma of displacement experienced by millions of Eastern European people during and after World War II.

The Soviet system of penal labor was created in 1920, and during World War II the Soviet Gulag (Glavnoe Upravlenie Lagerei, or Main Camp Administration) was developed, including huge networks of labor and exile camps and colonies with people from the Urals, Siberia, Central Asia, and Northern Russia ${ }^{1}$. It also included Eastern Europeans deported by Soviet rulers from annexed territories. The population of northeastern Romania was deeply affected by mass deportation. After the deportation of Polish people in 1939, the population from the territories annexed by the USSR in 1940, including from the Baltic States and from different regions of Romania, encountered the same fate ${ }^{2}$. Various reasons were given for deportation,

${ }^{1}$ More information about the history of Gulag and the lives of millions of people incarcerated there can be found in Anne Applebaum's volume Gulag: A History, New York 2003.

${ }^{2}$ L. Toker, Return from the Archipelago: Narratives of Gulag Survivors, Bloomington 2000, p. 19. 
regardless of actual evidence: alleged acts of spying, being considered a refugee from various other parts of Russia, refusal to submit to Soviet rule, farmers who resisted collectivization or had a good material life, those considered to be bourgeois, etc. Families were separated and belongings were lost. People were packed into train wagons and sent to the Siberian Gulag. Many of them died en route, and those who survived had only hunger, forced labor, and torture to look forward to. In June 1940, USSR sent an ultimatum to Romania that ended with the annexation of Bessarabia, North of Bukovina and Herța. Different social strata were targeted: bourgeois party activists, landowners, policemen, gendarmes, officers from the Tsarist and Romanian army, merchants, etc ${ }^{3}$ and 31,419 people were arrested and deported from Bessarabia, Bukovina and Herta in $1941^{4}$. The operations started in the middle of the night between 12th and 13th of June 1941. A list of people was already drafted, and families had only a few minutes to pack their belongings. Furthermore, they were only allowed to take around 40 kilograms with them for each family. Throughout the territories of Bessarabia and Bukovina, 1,315 wagons were specially sent to fulfil the necessities for the deportations ${ }^{5}$. The heads of the families were sent to the camps at Kozelshchina and Putivl. The rest of the members were sent to Kazakhstan and the West of Siberia. Besides the number of deportations that took place in June 1941, over 53,000 people from Moldavia were sent in labour camps throughout the territory of USSR. The second wave of deportations took place in the summer of 1949. The Soviet authorities "discovered" a large number of state enemies who were called Kulaks and on 28th of June 1949 the government of Moldavia adopted a decision called "On the deportation of Kulak families, landowners from the MSSR"[Moldavian Soviet Socialist Republic] ${ }^{6}$. The deportation started at 2 a.m. on the 6th of July 1949 and ended at 8 p.m. on the 7th of July. The result was the expulsion in Kazakhstan and Siberia of almost 31,000 people. In 1951 the deportations were based on the religious element and on the $1^{\text {st }}$ of April 1951 2,617 people were sent deep inside the Siberian territory.

Those who survived the deportation returned to their homes, but very few told or wrote their stories. Aniţa Nandriş-Cudla is one of the few women who recorded her struggle. The list of the deportees from Mahala, Nandriş-Cudla's villages, contains 602 names, many of them were names of children between one and three years old $^{7}$. Their fate is unknown. It is hard to imagine the suffering of these families, and the guilt the mothers must have felt over their inability to keep their children alive,

${ }^{3}$ P. Polian, Against their Will. The History and Geography of Forced Migrations in the USSR, Central European University Press 2004, p. 121.

${ }^{4}$ I. Caşu, "Stalinist terror in Soviet Moldavia, 1940-1953", [in:] K. McDermott, M. Stbbe (eds.), Stalinist terror in Eastern Europe, Elite purges and mass repression, Manchester University Press 2010, p. 41.

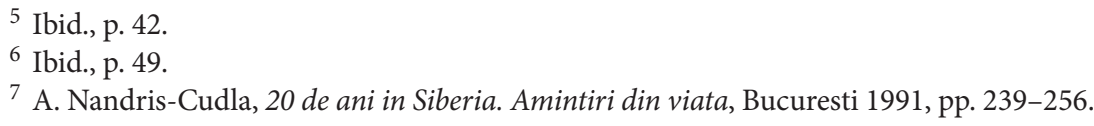


all the more so without access to their testimonies. Among other things, deportation means the separation of families. Usually men were arrested and sent to forced labor camps in Gulag, and the women and children were sent to various isolated places in Siberia, where they were also used as a free source of labor. Nandriş-Cudla's testimony speaks about the difficulties experienced by the deportees who, arriving in remote regions of Siberia without proper clothes or food supplies, were treated as state enemies. Locals feared and despised them, as they were told that the new arrivals were criminals that needed to be punished. When deportees managed to gain the trust of the locals and their living conditions began to improve, they were typically moved to a different area and had to begin again from scratch. The stories of these women, who struggled to keep their families alive in unimaginable conditions, represent an essential part of the deportation tragedy that is still largely unexplored.

Nandriş-Cudla begins her writing chronologically, telling the story of her childhood, when she first encountered social injustice. Her motivation in detailing these events seems to be related to the daily problems faced by those living through major historical tragedies, such as World War I. She wrote not for the sake of an exceptional story about an exceptional woman, but to transmit the life story of those subjected to historical injustices under a totalitarian regime, her family included. Moreover, she demonstrates how the mental strength she would later show was formed during her family's experience of the World War I. When she was a child, her village (Mahala, situated at seven $\mathrm{km}$ from Cernăuți/Chernovtsy) was on the front line of the war. Her family's background illustrates the main pillars of her life: the values and behavior patterns intergenerationally transmitted, cherished and respected not only by her but also her children. Her identity narrative focuses on the family and its values, particularly highlighted in the care of her mother, who was left paralyzed after she was beaten by Russian soldiers. Anița continued to care for her mother from childhood until her deportation, despite the challenges she faced as a mother of her own three children and the daily cares associated with providing for a family. Her story is interlinked with her mother's story, revealing the perception of the mother figure in the children's eyes. Many farmer women were used to working very hard to provide for their families. Anița, although a young wife and mother, with all the activities those roles entail, worked for the financial needs of her family, including raising the money for constructing their house. Women not only cared for their children and husbands, they were also involved in activities such as sewing or raising livestock for profit. All activities related to the house and domestic animals were in their care, illustrating the expression Anița referred to in her memoirs: a man is a guest in his house.

Nandriş-Cudla's brothers attended school and became professors and doctors. Reading the life writing of this woman, who had minimum of education, but proved to possess exceptional literary gifts, writing simple but evocative imagery, one wonders, how might her life have been under different social conditions - if she'd had access to the education her brothers had? Certainly she proved to be a very intelligent woman who faced life's challenges with great dignity and serenity. 
She and her family initially ran away when they found out that the Romanian authorities were leaving and their village would be occupied by Soviet rulers. However, she later submitted to her husband's fear of not losing their property and the family returned home - a decision that was regretted in the years to come. They were arrested in the middle of the night, June 13, 1941, and sent to Siberia. Separated from her husband and disabled mother, and with three children in her care, she faced deplorable conditions, defined by a very thin line between life, illness, and death. Without proper food, shelter and clothes her life became a nightmare. Her stories included details about her permanent search for food, including the way in which she gathered every bread crumbs and desperately searched the tundra to find wild berries to fight the scurvy, made clothes from old bags and mittens from dog hair, and fought against her permanent body deterioration. It was a world where the simple commodities were missing, there were no materials for clothes or shoes and with only 700 grams of bread for those who were working and less than half for children and old people. Some days they were just boiling water with a spoon of salt in order to fool their hunger. Her account records her belief that a superior force gave her the strength to endure and conquer her daily challenges, summarized by the Romanian proverb: where human beings put their hands to work, God puts his mercy. Her life in Siberia is summarized in her remark: "Multă frică şi multe altele înduram, dar toate le dam la o parte şi mă gîndiam numai una: să-mi pot salva viaţa mea şi a copiilor"8. As the fate of the deportees was outside of any legal context, they did not know what they were charged with or what the future held for them. As Tzvetan Todorov points out, deportees "were not condemned merely to forced labor. In fact, they were condemned to nothing, and the key to their situation lay exactly in the arbitrariness which victimized them" 9 . The journey to Siberia had already prepared them for the worst: transported like animals without food, the weaker ones did not survive the journey. Leona Toker vividly depicts life in the Soviet Gulag: "When not executed by the authorities or murdered by criminals or convicts, [the] victims face a lethal combination of chronic hunger, overwork, and neglect" ${ }^{\prime \prime}$. The conditions were similar for those deported; only the fences were missing. Nandriş-Cudla and her sons survived this ordeal for twenty years, and her life narrative offers glimpses of women's daily burdens: language difficulties, malignity on the part of the locals, general injustices, hunger, sickness, and death. Sick with typhus and unable to move she was punished with two months of prison because she was not able to achieve her monthly duty. The physical work was hard and without proper food it became a torture. A potato hidden under the clothes, a handful of wheat hidden in a shoe, all of these made the difference between a day of starvation and a day in which they felt

${ }^{8}$ Ibid., p. 95. "I endured a lot of fear and many others, but I put all of this away and thought only to save my own life and the lives of my children" (our translation).

9 T. Todorov, "Communist camps and their aftermath", Representations 49, special issue 1995, Winter, p. 121.

${ }^{10}$ L. Toker, op. cit., p. 21. 
it was a celebration only because they had something to eat. Hunger was a constant in their lives, and she felt the great weight of her children's lives depending on her ability to survive and to obtain food for them:

Cînd vedeai însă copilul că se uită în faţa ta galben şi palid la faţă şi-i picură lacrimi din ochi şi spune: mamă, tare mi-i foame, vă puteți închipui oare cum era inima mamei aceleia. ị̂ti venia în gînd să dai şi ultima zdrianță, numai să-i alini foamia copilului ${ }^{11}$.

Nandriş-Cudla's story is also the story of her children's experience in Siberia: working to obtain a piece of bread in a world where a handful of grain could make the difference between life and death. She speaks very well about her children, who seemed to understand their mother's struggle and tried to help her as they could, learning to catch wild birds for food, using horse hair, as thread or wire were out of reach. Their level of understanding over their current lives is impressive, and they are trying as best as they can to help their mother, and support each other. They were deported as children, started to work as any adult in hope to gain more to eat besides the 300 grams of bread they received. They returned home as adults, they passed from childhood into adulthood in deportation. Their mother wisely remarked: "Am petrecut acolo floaria vieții, cînd trebuiau copiii să criască, să prindă putere, cînd trebuiau copiii să deprindă cum să trăieşte, cum să se poarte cu lumia, să învețe ceva pentru viitorul lor" ${ }^{\prime 2}$. A family deportation is thus a tragedy that deeply affects the children, who lose their opportunity for education and financial stability in the face of bare survival. Without access to formal education and only with their mother as emotional support, the children spent in deportation their formative years, when a child learns to socialize, establish trusting human relations and discern between right and wrong.

Torn from her family and community, Nandriş-Cudla's feeling of displacement was so deep that she felt alive again only when she succeeded, after years of deportation, in reconnecting through letters with her brothers:

De cind am început să primesc scrisori de la scumpii mei frați, mi-a părut că am reînviat din morți. De cum ni-a răpit din cuibul nostru şi pînă m-am găsit cu fraţii mei am crezul că sint pierdută pentru totdeauna, într-aşa mare depărtare şi pustiitate am fost duşi ${ }^{13}$.

When she finally received approval to return home, she returned to a place where she had no relatives and no property. Her sons worked to regain their parents'

11 A. Nandris-Cudla, op. cit., p. 93. "When you see your pale and weak child looking at you with tears on his/her cheeks and telling you: 'Mother, I'm so hungry', can you imagine what was in a mother's heart! You would give your last rag to soothe his/her hunger" (our translation).

12 Ibid., p. 174. "We were forced to spend our prime of life there, when children should be growing strong, learning how to behave, and getting an education for their future" (our translation).

13 Ibid., p. 171. "Since I started to receive letters from my beloved brothers I felt that I was lifted from death. Since the time they took us from our home until I found my brothers again I believed that I was forever lost, as I was taken to such remote and faraway places" (our translation). 
house and the family tried to reintegrate, even though the community was no longer that of their childhood: many people had migrated, many had been killed, and many others had been deported and never returned.

Through Nandriş-Cudla's multilayered narrative we can re-appropriate the past and imagine the untold stories of countless women who struggled to survive in very harsh conditions.

As mentioned above, the topic of deportation in the Romanian literature is limited to autobiographical writings, and it focuses more on the deportation from Bessarabia rather than that from North Bukovina. Even here, the women's narratives are scarcely represented, and the accounts are therefore limited in terms of individual and collective memory, social, demographic, and economic effects, and so forth. A limited number of women publicly shared their stories (orally) and fewer still wrote down their stories. The Romanian Communist regime used national deportation as well, in which individuals or entire families were transported to different Romanian regions without any material support. Often deportees were abandoned in deserted areas, where those who survived learned to build rudimentary dwellings and obtain minimal food ${ }^{14}$.

The national neglect of deportation narratives was worsened by the fact that parts of Bukovina and all of Bessarabia were no longer Romanian territories after the war. Partially because of their limited number and influence, women's experiences of displacement are largely overlooked. Yet, as Maria Bucur remarks, many women orally transmitted their deportation stories: "In Romania women tend to play an important role in transmitting the oral narratives that help shape the collective memory of smaller communities. Women are central in organizing the rituals of burial and remembering for the dead in their families. In fact, they constitute the living memory of these dead"15. Unfortunately, these oral accounts have failed to largely transmit the experience of the past because they have not been written down. The result is a lack of women's influence concerning the register of public and collective memory. There is a considerable difference between the women's role in transmitting the knowledge/ memory of the past at the family level and their influence and the public and official level, where their stories represent alternative narratives. Two factors also contributing to this underrepresentation are the fact that the state played a significant role in shaping the public memory until 1989 and the post-1989 reluctance in dealing with past wrongs.

${ }^{14}$ Elena Spijavca is another woman who testified to the hard conditions suffered by those deported by the Communist regime in different parts of the country, though her testimony is more factual and uses a very dry literary style. See her book: Munci şi zile în Bărăgan, București 2004. More testimonies about the deportation as a means of punishment used by the Romanian Communist regime can be found on the website: memorialuldeportarii.ro.

${ }^{15}$ M. Bucur, "Women's stories as sites of memory: Gender and remembering Romania's World Wars", [in:] N. Wingfield, and M. Bucur (eds.), Gender \& War in Twentieth-Century Eastern Europe, Bloomington 2006, p. 187. 
Advised by her brother, Nandriş-Cudla wrote down her life story and asked her nephew to illegally disseminate her memoirs throughout Romania, despite the risks associated with this decision. Her testimony thus made its way to many who had not directly experienced the deportation trauma, but whose parents and grandparents had. The memoirs are an act of witnessing, privileging "that vantage point as a knowledgeable one, by virtue of having experienced those events. For both writers and their audience, memoirs reflect the assumption that personal experience renders the memory of the events more authentic than a narrative about the same event told by a distanced observer" 16 . As the first generation gradually disappears, life writing remains a vital source of collective memory/postmemory. Her memoirs were well received in Romania, by both professional writers and the public at large. The fact that the publisher decided to release the book without major modifications, keeping the style of the original manuscript - complete with her grammatical errors and regional language - made the book all the more valuable as a testimony of a simple woman who survived the ordeal of deportation in Siberia. She wrote her testimony without trying to improve the literary descriptions and to offer aesthetic value, and she wrote down her memories without giving attention to the possible audience. Her brother asked her to write her memories, thus in her mind the family was her audience and she wrote as she directly spoke with them, with honesty, wisdom, and affection. Younger generations sympathize with her testimony, as some online readings prove. She reminds many from the younger generation of their own grandmothers. The resemblance in language, attitude, values, behavior, etc., makes it possible for many who never experienced these traumatic events to empathize with those who did.

Marianne Hirsch created and developed in her studies the concept of postmemory as related to the experiences of the second generation that is remembered only based on the stories, images and representation transmitted by their parents. These experiences "were transmitted to them so deeply and affectively as to seem to constitute memories in their own right. Postmemory's connection to the past is thus actually mediated not by recall but by imaginative investment, projection and investment" ${ }^{\prime \prime}$. This is the memory of the generations that did not experienced directly the past events/traumas, but were so influenced by the family memories that they included these memories in their own register in a way that sometimes surpasses their personal memories. They know the past because through their family memories they became keepers of the past. What about those who do not have access to this type of memories? In her book The generation of postmemory Hirsch introduces new theoretical developments of the postmemory concept, speaking about "familial structures of mediation and representation" and "afilliative postmemory". Nandriş-Cudla's book was initially published because her nephew Gheorghe Nandriş managed to hide the

16 Ibid., p. 172.

17 M. Hirsch, The Generation of Postmemory: Writing and Visual Culture After the Holocaust, Columbia University Press 2012, p. 5. 
manuscript and bring it to Romania in 1982, long before the Communist regime collapsed in Central-Eastern Europe. The author kept this manuscript hidden in her attic for 17 years before she decided to give it to her nephew. The theoretical ground of the affiliative postmemory concept offers some glipmses over the way in which we relate our personal and collective narratives to the experiences lived and narrated in this book. Hirsch argues that the postmemory work "reactivate and reembody more distant social/national and archival/cultural memorial structures by reinvesting them with resonant individual and familial forms of mediation and aesthetic expression. Thus less directly affected participants can become engaged in the generation of postmemory which can thus persists even after all participants and even the familial descendants are gone"18. Acts of memory take a narrative form in order to sustain the personal and collective identity, and the memories that are transposed at the narrative level are "affectively colored, surrounded by an emotional aura" ${ }^{19}$. Imagining what others have felt and how they survived, we appeal to the affective resemblance, as we put ourselves in others' places using our imagination and based on emotional memory ${ }^{20}$. Empathy involves imaginary experience of another person's emotions when facing a specific event and, in this way, making the decision to understand the other person's perspective. At this level, affiliative postmemory becomes essential.

Nandriş-Cudla's book was first published in 1991 when the echo of her memories was contained to only small groups of people, predominantly intellectuals. During those years Romania's population was taking the first few steps in the process of coming to terms with the past. But the book was republished in 2006, 2010, 2012 and 2013 , a clear sign that this country was finally ready to deal with some of the past events that affected its people.

The young generations are embracing Nandriş-Cudla's story and even more they are perceiving her as a woman of great character, discovering that not only is her book an invitation to find out more about the terror of the communist regime but also a testimony of dignity, courage, and love ${ }^{21}$.

The comments posted on the website Goodreads present the readers as skeptical at first, the majority admits that they were not very attracted by the book at the beginning, but after the first pages they were captured and emotionally lived Nandriş-Cudla's life.

The interest of the younger generation in Nandriş-Cudla's story is also shown at the performing level by the Bucharest National Theatre that alongside the "Ion Sava" Centre for Theatre Research and Creation has started a project entitled: "Procesul

${ }^{18}$ M. Hirsch, "The generation of postmemory", Poetics Today 29.1, Spring 2008, p. 111.

19 M. Bal, "Introduction", [in:] M. Bal, J.V. Crewe, L. Spitzer (eds.), Acts of Memory. Cultural Recall in the Present, University Press of New England, 1999, p. VIII.

20 See F. Cappelletto, "Long-term memory of extreme events: From autobiography to history", The Journal of the Royal Anthropological Institute 9.2, 2003, pp. 241-260.

${ }^{21}$ See for example the websites: http://www.bookblog.ro, http://www.buburuzabia.blogspot.ro, and www.goodreads.com. 
comunismului prin teatru" (The process of Communism through theatre). As part of the project, director Sorin Misiriantu and actress Amalia Ciolan bring Anița Nandriş-Cudla to life in a one-woman show called "20 years in Siberia". The premiere of the show took place on 7th of February 2015. This endeavour was also followed by the radio story - "Anița Nandriș-Cudla, Memories from life", presented by Radio Romania Cultural in November 2015. Nandriş-Cudla's story was also presented beyond the borders of Romania. For instance a performance in Munich - the "Ballad of the girls from older days" - presents the life of three women: Anița Nandriş-Cudla, Ana Novac and Bettina Schuller, alongside their experiences from the Siberian tundra, concentration camps and the parading of the Nazi soldiers.

The process of recollecting the past involves all of the emotions associated with the traumatic experiences of the survivors and victims of oppressive regimes. The narrative form permits the intergenerational transmission of memory and knowledge, even if, as Marianne Hirsch observes in Generation of Postmemory, there are traumas that cannot be fully understood or imaginatively recreated by the second or third generations. The past must be explored not only at the level of official memory discourse; it must also offer more public space to alternative and marginal narratives. The process of coming to terms with the past has been, in many former Communist countries from Eastern Europe, inhibited by social and political impediments. This fact has profoundly affected post-Communist society in terms of social bond and trust. In some countries, the process has focused on what was named "the scapegoat" of the former regime. The ruling political class and the mass media have centered on finding and publicly disclosing informants for the political police, not on offering a legislative context for punishing the real actors, and certainly not on publicly cherishing the memories of the victims and survivors. ${ }^{22}$ It is the argument of this paper that enriching the knowledge of the past through the intergenerational transmission of memories and exploration of the narratives of the victims, the process of coming to terms with the past will become possible at the personal level and at the social level. In this way, it is also possible to recreate or reinforce the social trust weakened by years of repression, abuse, and deprivations.

\section{Bibliography}

Applebaum, A. 2003. Gulag: A History. New York: Doubleday.

Applebaum, A. (eds.). 2011. Gulag Voices: An Anthology. New Haven-London: Yale University Press.

Bal, M. 1999. "Introduction." In M. Bal, J.V. Crewe, L. Spitzer (eds.). Acts of Memory. Cultural Recall in the Present. Hanover: University Press of New England. VII-XVII.

${ }^{22}$ For more details about broken and divided societies, please see the volume Life Writings and Politics of Memory in Eastern Europe, edited by Simona Mitroiu, especially the chapters about Hungary, Romania, and former Yugoslavia. 
Bucur, M. 2006. "Women's stories as sites of memory: Gender and remembering Romania's World Wars." In N.M. Wingfield, M. Bucur (eds.). Gender \& War in Twentieth-Century Eastern Europe. Bloomington: Indiana University Press. 171-192.

Cappelletto, F. 2003. "Long-term memory of extreme events: From autobiography to history." The Journal of the Royal Anthropological Institute 9.2. 241-260.

Caşu, I. 2010. "Stalinist terror in Soviet Moldavia, 1940-1953." In K. McDermott, M. Stbbe (eds.). Stalinist Terror in Eastern Europe, Elite purges and Mass repression. Manchester: Manchester University Press. 39-56.

Hirsch, M. 2012. The Generation of Postmemory: Writing and Visual Culture after the Holocaust. New York: Columbia University Press.

Hirsch, M. 2008. “The generation of postmemory." Poetics Today 29.1. Spring. 103-128.

Gheith, J.M., Jolluk, K.R. (eds.). 2011. Gulag Voices. Oral Histories of Soviet Incarceration and Exile. New York: Palgrave Macmillan.

Mitroiu, S. 2015. "Introduction." In S. Mitroiu (eds.). Life writing and politics of memory in Eastern Europe. New York: Palgrave Macmillan. 1-25.

Nandriş-Cudla, A. 2014. 20 de ani în Siberia. Amintiri din viaţă. Bucureşti: HumAnițas. E-book edition.

Polian, P. 2004. Against their Will. The History and Geography of Forced Migrations in the USSR. Budapest: Central European University Press.

Todorov, T. 1995. "Communist camps and their aftermath." Spec. issue of Representations 49. Winter. DOI: $10.2307 / 2928752.120-132$.

Toker, L. 2000. Return from the Archipelago: Narratives of Gulag Survivors. Bloomington: Indiana University Press.

Przyjęto do druku/Accepted for publication: 4.02.2017 